\title{
Residual Stresses Distribution Through Thick HVOF Sprayed Inconel 718 Coatings
}

C. Lyphout, P. Nylén, A. Manescu, and T. Pirling

\section{Erratum to: Journal of Thermal Spray \\ Technology \\ DOI 10.1007/s11666-008-9242-9}

This article was mistakenly published without the following credit line:

This article is an invited paper selected from presentations at the 2008 International Thermal Spray Conference and has been expanded from the original presentation. It is simultaneously published in Thermal Spray Crossing Borders, Proceedings of the 2008 International Thermal Spray Conference, Maastricht, The Netherlands, June 2-4, 2008, Basil R. Marple, Margaret M. Hyland, Yuk-Chiu Lau, Chang-Jiu Li, Rogerio S. Lima, and Ghislain Montavon, Ed., ASM International, Materials Park, OH, 2008.

The online version of the original article can be found under doi:10.1007/s11666-008-9242-9.

C. Lyphout and P. Nylén, University West, Trollhättan, Sweden; A. Manescu, Università Politecnica delle Marche, Ancona, Italy; and T. Pirling, Laue-Langevin Institute (ILL), Grenoble, France. Contact e-mail: christophe.lyphout@hv.se. 